\title{
Review Article \\ Effects of Commercially Available Dietary Supplements on Resting Energy Expenditure: A Brief Report
}

\author{
Roger A. Vaughan, ${ }^{1,2,3}$ Carole A. Conn, ${ }^{3}$ and Christine M. Mermier ${ }^{1}$ \\ ${ }^{1}$ Department of Health, Exercise and Sports Science, University of New Mexico, USA \\ ${ }^{2}$ Department of Biochemistry and Molecular Biology, University of New Mexico Health Sciences Center, USA \\ ${ }^{3}$ Department of IFCE: Nutrition, University of New Mexico, USA
}

Correspondence should be addressed to Roger A. Vaughan; vaughanr@unm.edu

Received 18 September 2013; Accepted 10 October 2013; Published 2 January 2014

Academic Editors: H. Schröder, C. Soulage, and M. Tesauro

Copyright (C) 2014 Roger A. Vaughan et al. This is an open access article distributed under the Creative Commons Attribution License, which permits unrestricted use, distribution, and reproduction in any medium, provided the original work is properly cited.

\begin{abstract}
Commercially available dietary products advertised to promote weight loss are an underresearched but heavily purchased commodity in the United States. Despite only limited evidence, interest in dietary supplements continues to increase. This work uniquely summarizes the current evidence evaluating the efficacy of several over-the-counter thermogenic products for their effects on resting energy expenditure. Currently, there is some evidence suggesting dietary products containing select ingredients can increase energy expenditure in healthy young people immediately following consumption (within 6 hours). It is unclear if supplement-induced increases in metabolic rate provide additional benefit beyond that provided by dietary constituents that contain similar ingredients. It is also unclear if dietary supplements are effective for weight loss in humans.
\end{abstract}

\section{Introduction}

Obesity has rapidly become a leading cause of death without a foreseeable resolution in the near future. Most clinicians believe the combination of food overconsumption with sedentary lifestyle synergistically promote weight gain and obesity. The importance of restrictive dietary practices in combination with physical activity are of undeniable importance for weight loss and general health [1,2]; however, the role of genomics and corresponding interactions with dietary and exercise practice still remain largely ill-defined as the field is still in its infancy [3]. A variety of therapies are currently available to combat obesity; however recent trends in obesity prevalence provide strong evidence that current interventions are insufficient to effectively slow the development of obesity and related comorbidities [1-3].

The role which food chemicals and dietary components may play in obesity therapeutics is increasing interest. In obesity research, several classes of chemicals including methylxanthines, polyphenols, capsaicin (capsaicinoids/capsinoids), polyunsaturated fats, and many other components found in food have shown some promise in promoting a metabolic advantage for weight loss $[4,5]$. As a result of preliminary data supporting some of the aforementioned ingredients, producers of commercially available dietary supplements often include one or many of these components in their products [5]. Dietary supplements are sold for a variety of purposes, including weight loss, and many ingredients are promoted specific benefits such as increased thermogenesis.

Dietary supplements are unique because unlike pharmaceutical agents, they do not require close regulation of content, function, or safety prior to consumption by humans [6] and are generally not recommended by healthcare professionals [7]. Because of limited regulation, it is not uncommon for single ingredients to be promoted for a promiscuous variety of unsubstantiated functions and health benefits. Although subjected to limited regulation, it is mandated that all dietary supplements be marked with a disclaimer stating the lack of support by the FDA for all claims. Supplements sold as thermogenic products for weight loss and/or energy augmenters are often promoted to cause rapid weight loss, often times independent of calorie restriction or physical activity. Despite resistance from healthcare professionals, consumer interest in dietary supplements continues to surge 
[8]. According to NHANES questionnaire data from roughly 12,000 participants, approximately $50 \%$ of those surveyed used dietary supplements in the past 30 days [8]. Use was most common among 20-30-year-old participants, and more common in women than in men [8]. Interestingly when asked to select the motivating factor for supplement consumption, "weight loss" or "get more energy" were reported as the motivation for approximately $14 \%$ of participants, both of which were also more common in women participants [8]. This work seeks to summarize current research evaluating commercially available dietary supplements sold as stimulators of thermogenesis and increased metabolic rate leading to weight loss.

\section{Individual Ingredients as Metabolic Stimulators}

2.1. Caffeine and Xanthine Metabolites. Of the available dietary supplements marketed for weight loss, many contain a blend of ingredients that includes caffeine. Caffeine has previously been shown to dose-dependently heighten resting energy expenditure in adult humans, both normal and overweight $[5,9-14]$. Despite some conflicting data, it is generally accepted that caffeine effectively stimulates the central nervous system and increases metabolic rate in humans [14-16]. Caffeine functions through inhibition of phosphodiesterase (PDE) and through stimulation of adenosine receptors, leading to accumulation of intracellular 3,5-cyclic-adenosine monophosphate (cAMP) which is metabolically excitatory for cells $[11,12,14]$.

2.2. $\beta_{2}$-Adrenergic Receptor Agonists. Like caffeine, stimulators of $\beta_{2}$-adrenergic receptors such as ephedra/ephedrine have been another primary component found in supplemental thermogenic products $[9,11,14]$. Following the restriction of ephedra use, similar chemical analogs such as synephrine from bitter orange extract became widely accepted replacements [17-20]. $\beta_{2}$-adrenergic receptor agonists work to increase cAMP biosynthesis, while caffeine inhibits the breakdown of cAMP by PDE [14]. Additionally, salicylates inhibit prostaglandins further allowing the accumulation of cAMP [14]. Taken together, caffeine, $\beta_{2}$-adrenergic receptor agonists and salicylates function to synergistically increase cAMP accumulation and metabolic rate [14].

2.3. Green Tea Extract Polyphenols. Several other dietary stimulators of metabolism are thought to function by augmenting the accumulation of cAMP [14]. Green tea extract is rich in polyphenols and is heavily promoted for health benefits including increased metabolism [4, 12-14, 21-28]. Epigallocatechin gallate (EGCG), epigallocatechin (EGC), epicatechin gallate (ECG), and epicatechin (EC) are believed to cause most of green tea's beneficial effects [5]. Other teas such as black tea, thearubigins, and theaflavins share similar effects to those found in green tea $[4,29]$. Green tea extract appears to offer some thermogenic effect when coupled with caffeine resulting in increased energy expenditure [14, 22, 30]. In contrast, isolated green tea polyphenol ingestion independent of caffeine does not appear to increase metabolic rate; however it does increase indicators of fat metabolism in some populations $[14,22,30]$.

Green tea is purported to function by inhibiting the degradation of $\beta_{2}$-adrenergic receptor agonists such as norepinephrine by the enzyme catechol O-methyltransferase (COMT), thereby increasing intracellular cAMP $[4,12]$. Again, the combination of green tea polyphenols with caffeine cause a synergistic effect further increasing cAMP. Recently, the effects and mechanisms of green tea extract in human metabolism were reviewed and it was suggested that the mechanism of COMT inhibition is possibly a product of in vitro experimental conditions, because COMT inhibition experiments have yet to identify a specific catechin inhibitor, or determine if the active polyphenol is an inhibitor, a substrate of COMT, or a combination [31]. Additionally, the mechanisms of the hypothesized downstream effect of COMT inhibition resulting in heightened fat metabolism have yet to be elucidated experimentally [31]. In addition to COMT inhibition, it is theorized that effects of green tea extract are also a function of metabolic gene activation. Specifically, green tea may function to inhibit adipogenic genes such as peroxisome proliferator-activated receptor (PPAR $\gamma)$ and sterol regulatory element binding protein-1c (SREBP-1c) and increase the expression of genes that increase energy expenditure and mitochondrial biogenesis including nuclear respiratory factors (NRF), mitochondrial uncoupling protein-3 (UCP3), peroxisome proliferator-activated receptor $(\operatorname{PPAR} \alpha)$, and peroxisome proliferator-activated receptor $\gamma$ coactivator- $1 \alpha$ (PGC- $1 \alpha$ ), leading to increased oxidative and metabolic capacities [31].

2.4. Capsaicinoids and Capsinoids. Another common con stituent of thermogenic products is the capsaicinoids/ capsinoids, components found in spicy foods such as chili pepper and cayenne $[32,33]$. Available data suggests that supplemental capsaicinoids/capsinoids effectively increase resting energy expenditure, although findings have been inconsistent [32-34]. Capsaicinoids are believed to function by increasing catecholamine release, heightening sensitivity to circulating catecholamines, or a combination thereof [33]. Figure 1 summarizes the proposed mechanisms of the abovementioned individual ingredients commonly found in commercially available thermogenic products.

\section{Propriety and Commercially Available Thermogenic Products}

3.1. Proprietary Products. Several previous investigations have identified that commercially available products increase resting energy expenditure in a variety of subjects, most frequently using young healthy subjects (Table 1). Most commonly these products contain several of the following: caffeine, green tea, capsaicin, and catecholamine-like compounds (synephrine). In general, most investigations evaluated changes in energy expenditure within 6 hours of consumption. While the magnitude of the individual supplement's effect on 


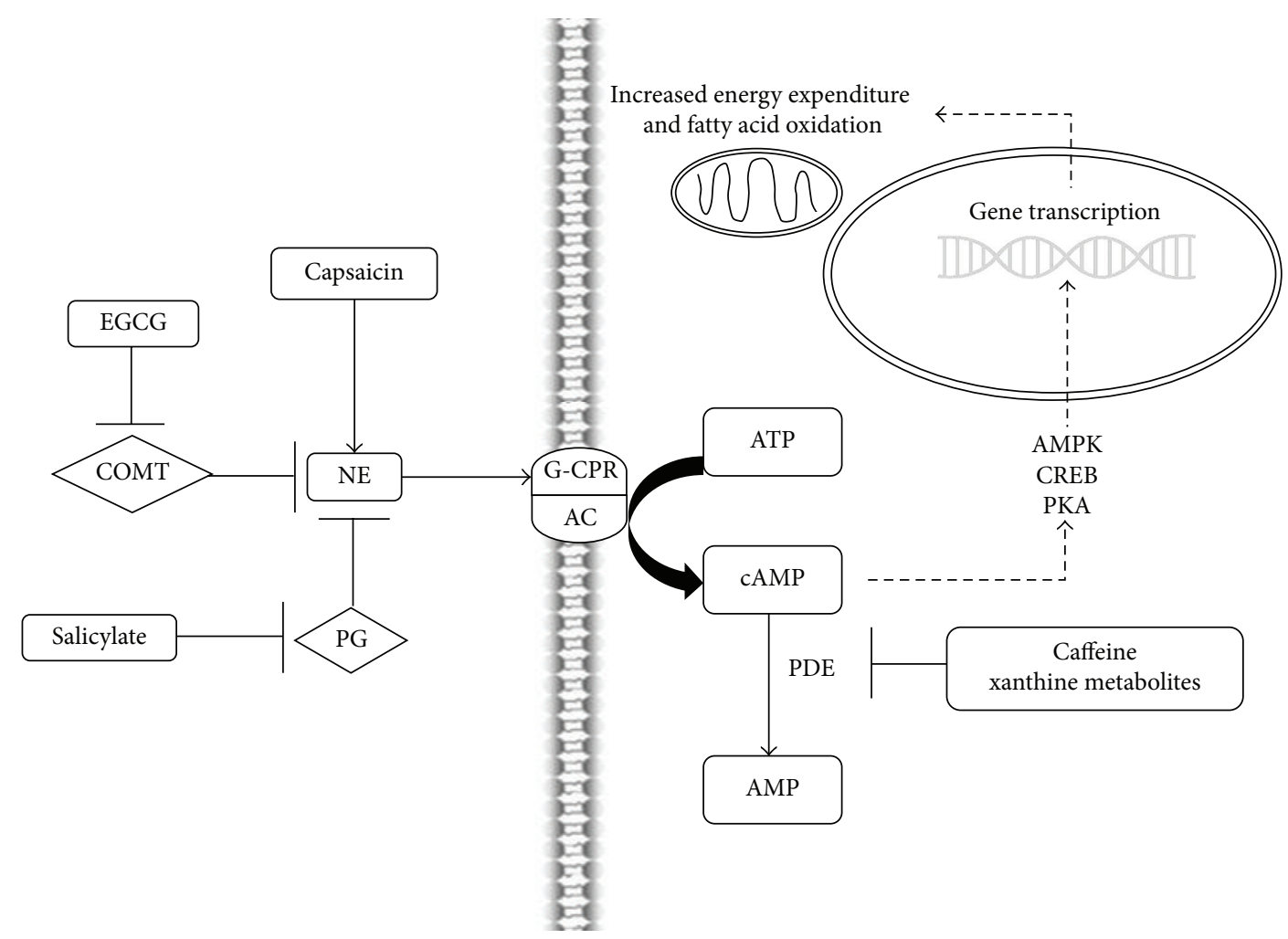

FIGURE 1: Summary of proposed mechanisms of common ingredients in thermogenic products. adenylate cyclase (AC), adenosine monophosphate (AMP), 3,5-cyclic-adenosine monophosphate (cAMP), 5' adenosine monophosphate-activated protein kinase (AMPK), adenosine triphosphate (ATP), catechol O-methyltransferase (COMT), cAMP-related element binding protein (CREB), epigallocatechin gallate (EGCG), G-coupled protein receptor (G-CPR), prostaglandin (PG), protein kinase A (PKA), norepinephrine (NE), and phosphodiesterase (PDE).

energy expenditure seems to vary depending on the ingredients consumed, the increase in energy expenditure is similar to previous observations using individual ingredients such as caffeine, ranging from 50 to $200 \mathrm{k}$ cals per hour immediately following ingestion. Although this increase is experimentally significant, it must be stressed that the effect is time-dependent and energy expenditure appears to return to basal levels 6 hours following consumption. Previous acute ( 24 hours or less) investigations with caffeine alone or green tea with caffeine showed approximately a $4 \%$ increase in 24 hour metabolic rate $[5,10,12,14]$ which approximates the increases seen with selected thermogenic products. Extended treatment for up to 8 weeks has also shown increased resting energy expenditure, suggesting that regular green tea consumption with select stimulants can continuously cause an increase in metabolism $[35,36]$.

Despite evidence that several of the single ingredients previously described have been shown to increase metabolic rate, there is some question about the efficacy of advertised dietary products for weight reduction. Hasani-Ranjbar and colleagues selectively identified dozens of studies which implicate natural products in the reduction of body weight in humans [6]. The investigations reviewed ingredients frequently found in dietary supplements including caffeine, ephedra, and a variety of herbal agents, many of which function in part as antioxidants [6]. These studies included experimental designs lasting from as little as 4 weeks to up to 9 months without controlling for exercise and/or concurrent energy restriction. In general, there appears to be some evidence that thermogenic products may partially aid in weight loss, although it is difficult to identify the magnitude because of between-study variables.

\section{Limitations to Current Observations}

4.1. Individual Ingredients. One possible contributor to discrepancies within the literature regarding efficacy of individual ingredients is experimental variability. Multiple confounds exist in energy expenditure measurements such as duration of measurement, type of analytical and measurement software, duration of measurement after ingestion of stimulant, and the amount of purported metabolic stimulator consumed. An additional issue is that much of the original measurements were conducted several decades ago. Moreover, significant biological differences between demographics may also contribute to varied response across similar studies.

4.2. Commercial Products. Proprietary blends found within dietary supplements have numerous issues that are not encountered when testing pharmaceutical grade single chemicals (such as caffeine). For example, dietary supplements may 
TABLE 1: Investigations evaluating the effects of thermogenic products on resting energy expenditure (REE) following acute (24 hours or less) and extended (longer than 24 hours).

\begin{tabular}{|c|c|c|c|}
\hline Subjects & Ingredients & Findings & Author \\
\hline \multicolumn{4}{|c|}{ Effects of acute consumption of dietary supplements on energy expenditure } \\
\hline $\begin{array}{l}\text { Obese men } \\
(N=19)\end{array}$ & $\begin{array}{l}\text { Green tea extract } 750 \mathrm{mg} \text { L-tyrosine } 609 \mathrm{mg} \text { caffeine } \\
151 \mathrm{mg} \text { cayenne } 225 \mathrm{mg} \text { calcium } 1965 \mathrm{mg}\end{array}$ & $\begin{array}{l}\text { Supplement containing } \\
\text { bioactive food ingredients } \\
\text { increased daily REE by } \\
200 \mathrm{~kJ} \text { or } 2 \%(48 \mathrm{kcal})\end{array}$ & $\begin{array}{l}\text { Belza and Jessen } \\
2005[34]\end{array}$ \\
\hline $\begin{array}{l}\text { Healthy men } \\
\text { and women } \\
(N=20)\end{array}$ & $\begin{array}{l}\text { Caffeine anhydrous toothed clubmoss (Huperzia } \\
\text { serrata) yerba mate (Llex paraguariensis) } 3^{\prime}-5^{\prime} \text {-CAMP } \\
\left(3^{\prime}-5^{\prime} \text {-cyclic adenosine monophosphate) synephrine }\right. \\
\text { HCL R-beta-methylphenylethylamine } \\
\text { N-Methyl-B-phenylethylamine yohimbe } \\
\text { Methyl-hordenine }\end{array}$ & $\begin{array}{l}\text { Increased REE } 59 \pm 26 \\
\text { kcal. } 6 \text { hrs, serum } \\
\text { epinephrine, } \\
\text { norepinephrine, glycerol, } \\
\text { systolic and diastolic BP }\end{array}$ & $\begin{array}{l}\text { Bloomer et al. } 2009 \\
\text { [37] }\end{array}$ \\
\hline $\begin{array}{l}\text { Healthy men } \\
\text { and women } \\
(N=10)\end{array}$ & $\begin{array}{l}\text { Caffeine anhydrous toothed clubmoss (Huperzia } \\
\text { serrata) yerba mate (Llex Paraguariensis) } 3^{\prime}-5^{\prime} \text {-CAMP } \\
\left(3^{\prime}-5^{\prime} \text {-cyclic adenosine monophosphate) synephrine }\right. \\
\text { HCL R-beta-methylphenylethylamine } \\
\text { N-mehtyl-B-phenylethylamine yohimbe } \\
\text { Methyl-hordenine }\end{array}$ & $\begin{array}{l}\text { Increased REE, increased } \\
\mathrm{HR} \text {, no change in BP }\end{array}$ & $\begin{array}{l}\text { Hoffman et al. } \\
2009[38]\end{array}$ \\
\hline $\begin{array}{l}\text { Healthy men } \\
\text { and women } \\
(N=12)\end{array}$ & $\begin{array}{l}\text { Caffeine anhydrous toothed clubmoss (Huperzia } \\
\text { serrata) yerba mate (Llex paraguariensis) } 3^{\prime}-5^{\prime} \text {-CAMP } \\
\left(3^{\prime}-5^{\prime} \text {-cyclic adenosine monophosphate) synephrine }\right. \\
\text { HCL R-beta-methylphenylethylamine } \\
\text { N-mehtyl-B-phenylethylamine yohimbe } \\
\text { Methyl-hordenine }\end{array}$ & $\begin{array}{l}\text { Increased REE } 45,60,120 \\
\text { minutes after ingestion } \\
\text { with no change in HR or BP }\end{array}$ & $\begin{array}{l}\text { Jitomir et al. } 2008 \\
\text { [39] }\end{array}$ \\
\hline $\begin{array}{l}\text { Healthy men } \\
\text { and women } \\
(N=8)\end{array}$ & $\begin{array}{l}\text { Caffeine anhydrous, guarana, yerba mate green tea } \\
\text { extract, L-carnitine L-tartrate, pathothenic acid, } \\
\text { chromium picolinate, proprietary blends containins, } \\
\text { AssuriTea green tea extract, Salvia sclarea, raspberry } \\
\text { ketones and Capsicum annum extract, plus l-tyrosine, } \\
\text { Salix alba, Zingiber officinale, fucus vesiculosus, Panax } \\
\text { ginseng, bioperineW }\end{array}$ & $\begin{array}{l}\text { Increased REE } 60,120,180 \text {, } \\
240 \text { minutes after ingestion }\end{array}$ & $\begin{array}{l}\text { Outlaw et al. } 2013 \\
\qquad[40]\end{array}$ \\
\hline $\begin{array}{l}\text { Healthy men } \\
\text { and women } \\
(N=28)\end{array}$ & $\begin{array}{l}\text { Supplement caffeine } 200 \mathrm{mg} \text {, capsicum extract } \\
33.34 \mathrm{mg} \text {, Niacin } 20 \mathrm{mg} \text {, Bioperine } 5 \mathrm{mg}\end{array}$ & $\begin{array}{l}\text { Increased REE } 50 \text { minutes } \\
\text { after consumption with } \\
\text { elevated HR and BP }\end{array}$ & $\begin{array}{l}\text { Ryan et al. } 2009 \\
\text { [32] }\end{array}$ \\
\hline $\begin{array}{l}40 \text { male and } \\
40 \text { female } \\
\text { healthy } \\
\text { young } \\
\text { subjects }\end{array}$ & $\begin{array}{l}1 \mathrm{mg} \text { capsinoids in } 199 \mathrm{mg} \text { of rapeseed oil and } \\
\text { medium-chain triglycerides }\end{array}$ & $\begin{array}{l}\text { No change in REE or } \\
\text { weight but increased fat } \\
\text { oxidation }\end{array}$ & $\begin{array}{l}\text { Snitker et al. } 2009 \\
\text { [41] }\end{array}$ \\
\hline $\begin{array}{l}10 \text { healthy } \\
\text { subjects per } \\
\text { treatment }\end{array}$ & $\begin{array}{l}600 \mathrm{mg} \text { naringin, } 50 \mathrm{mg} \text { p-synephrine } \\
100 \mathrm{mg} \text { hesperidin, } 50 \mathrm{mg} \text {-synephrine, } 600 \mathrm{mg} \\
\text { naringin } \\
1000 \mathrm{mg} \text { hesperidin, } 50 \mathrm{mg} \text {-synephrine, } 600 \mathrm{mg} \\
\text { naringin }\end{array}$ & $\begin{array}{l}\text { Increased REE } 129 \mathrm{kcal} \\
\text { Increased REE } 183 \mathrm{kcal} \\
\text { Increased REE } 79 \mathrm{kcal}\end{array}$ & Stohs et al. 2011 [17] \\
\hline $\begin{array}{l}8 \text { male and } 10 \\
\text { female } \\
\text { healthy } \\
\text { young } \\
\text { subjects }\end{array}$ & $\begin{array}{l}442 \mathrm{mg} \text { of a proprietary: } 100 \mathrm{mg} \text { of caffeine, } 230 \mathrm{mg} \text { of } \\
\text { green tea extract, L-tyrosine, L-taurine, chocamine, } \\
\text { white willow extract, yohimbine- } \mathrm{HCl} \text {, vinpocetine }\end{array}$ & $\begin{array}{l}\text { Increased REE } 60,120,180 \\
\text { minutes after ingestion }\end{array}$ & $\begin{array}{l}\text { Wilborn et al. } 2009 \\
{[42]}\end{array}$ \\
\hline $\begin{array}{l}\text { Healthy men } \\
\text { and women } \\
(N=60)\end{array}$ & $\begin{array}{l}\text { Caffeine, citrus aurantium, garcinia, cambogia and } \\
\text { chromium polynicotinate }\end{array}$ & $\begin{array}{l}\text { Significantly increased REE } \\
\text { at } 60,120,180 \mathrm{~min}\end{array}$ & $\begin{array}{l}\text { Dalbo et al. } 2008 \\
{[43]}\end{array}$ \\
\hline
\end{tabular}


TABle 1: Continued.

\begin{tabular}{|c|c|c|c|}
\hline Subjects & Ingredients & Findings & Author \\
\hline $\begin{array}{l}18 \text { healthy } \\
\text { young men }\end{array}$ & $\begin{array}{l}1.5 \mathrm{mg} \text { capsinoids in } 199 \mathrm{mg} \text { of rapeseed oil and } \\
\text { medium-chain triglycerides }\end{array}$ & $\begin{array}{l}\text { EE increased by } 15.2 \mathrm{~kJ} / \mathrm{h} \\
(\mathrm{BAT}+)(5 \mathrm{kcals} / \text { hour}) \\
\text { groups } 1 \text { hours after } \\
\text { ingestion }\end{array}$ & $\begin{array}{l}\text { Yoneshiro et al. } \\
\quad 2012[44]\end{array}$ \\
\hline \multicolumn{4}{|c|}{ Effects of extended consumption of dietary supplements on energy expenditure } \\
\hline $\begin{array}{l}\text { Healthy men } \\
\text { and women } \\
(N=8)\end{array}$ & $\begin{array}{l}\text { pantothenic acid, } 40 \mathrm{mg} \text {; green tea leaf extract } 200 \mathrm{mg} \text {; } \\
\text { guarana extract ( } 198 \mathrm{mg} \text { of caffeine), } 550 \mathrm{mg} \text {; bitter } \\
\text { orange }(9 \mathrm{mg} \text { of synephrine), } 150 \mathrm{mg} \text {; white willow bark } \\
\text { extract ( } 7.5 \mathrm{mg} \text { of salicin), } 50 \mathrm{mg} \text {; ginger root, } 10 \mathrm{mg} \text {; } \\
\text { proprietary blend (L-tyrosine, L-carnitine, naringin), } \\
375 \mathrm{mg} \text {, phenylephrine ( } 20 \mathrm{mg})\end{array}$ & $\begin{array}{l}\text { Increased REE with } \\
\text { increased body weight }\end{array}$ & $\begin{array}{l}\text { Greenway et al. } \\
2006[36]\end{array}$ \\
\hline $\begin{array}{l}\text { Obese } \\
\text { subjects } \\
(N=80)\end{array}$ & $\begin{array}{l}\text { Green tea extract } 750 \mathrm{mg} \text { L-tyrosine } 609 \mathrm{mg} \text { caffeine } \\
151 \mathrm{mg} \text { Cayenne } 225 \mathrm{mg} \text { calcium } 1965 \mathrm{mg}\end{array}$ & $\begin{array}{l}\text { Supplement increased REE } \\
\text { by } 87.3 \mathrm{~kJ}(21 \mathrm{kcal}) \text { sustained } \\
\text { for } 8 \text { weeks with reduced } \\
\text { body fat mass }\end{array}$ & $\begin{array}{c}\text { Belza et al. } 2007 \\
{[35]}\end{array}$ \\
\hline
\end{tabular}

vary in content from one lot to the next, suggesting some batches function better than others. Additionally, supplements are not required to third-party test products for purity and content, which allows for the possibility that nonlisted ingredients are included and ingredients that are purportedly included are missing. Such inconsistencies would likely inflate the variability of experimental measurement, contributing to inconsistencies in the reported effects of dietary supplements. Perhaps the most significant limitation to commercially available dietary supplements is the near-complete absence of scholarly evidence supporting individual product safety and efficacy. Another interesting and significant variable worth discussing is the matter of funding for research on dietary supplements. Multiple articles disclose that funding is contributed by the companies which market the product for retail purposes. This is not surprising because cost of biological research continues to increase while funding opportunities remain limited; therefore it is logical that select companies have outsourced primary research opportunities to the university setting. Surprisingly, many dietary supplements advertise one or multiple nonbiased studies illustrating efficacy of their product; however often times these studies have not been systematically peer-reviewed or readily shared with the scientific community making the original research difficult to locate. In addition, identification and tracking of adverse events with the majority of studies would not meet requirements for similar pharmaceutical agents [6]. Of the known adverse effects, dry mouth, insomnia, nervousness, palpitations, headache hypertension, arrhythmias, myocardial infarction, stroke, and seizures have been linked to consumption of ingredients such as caffeine and ephedra, suggesting a major need for further safety evaluation prior to consumption $[6,7]$. Lastly, along with limited evidence of whole-body efficacy and safety, there is inadequate evaluation of the molecular effects of commercially available dietary supplements. Our lab previously demonstrated that select dietary supplements containing a variety of ingredients could effectively increase skeletal muscle metabolism and mitochondrial content in vitro; however additional information is required to adequately describe cell- and tissue-specific effects of thermogenic products $[45,46]$.

\section{Concluding Remarks}

Increasing obesity prevalence and consumer interest in thermogenic dietary supplements support the need for further research of these and other supplement ingredients. From the available evidence, it appears that commercially available dietary supplements advertised to stimulate metabolism have the propensity to increase metabolic rate. Despite significant increases in resting energy expenditure, it is doubtful that commercially available thermogenic products stimulate metabolism more than consumption of food products containing equivocal content of caffeine/stimulants and/or polyphenols. Moreover, it should be mentioned that increases in metabolism induced by food or dietary supplement are small, contributing only subtly to metabolic rate. Additional research is necessary to identify the precise mechanisms by which commonly consumed ingredients function to alter energy expenditure and what corresponding molecular adaptations may develop.

\section{Abbreviations}

AC: Adenylate cyclase

AMP: Adenosine monophosphate

AMPK: 5'Adenosine monophosphate-activated protein kinase

ATP: Adenosine triphosphate

cAMP: 3,5-cyclic-adenosine monophosphate

COMT: Catechol O-methyltransferase

CREB: cAMP-related element binding protein

EGCG: Epigallocatechin gallate

EGC: Epigallocatechin

ECG: Epicatechin gallate

EC: Epicatechin

G-CPR: G-Coupled protein recepetor

PG: Prostaglandin 


$\begin{array}{ll}\text { PKA: } & \text { Protein kinase A } \\ \text { NE: } & \text { Norepinephrine } \\ \text { NRF: } & \text { Nuclear respiratory factors } \\ \text { PGC-1 } \alpha: & \begin{array}{l}\text { Peroxisome proliferator-activated receptor } \\ \gamma \text { coactivator-1 } \alpha\end{array} \\ \text { PPAR } \alpha: & \begin{array}{l}\text { Peroxisome proliferator-activated } \\ \text { receptor } \alpha\end{array} \\ \text { PPAR } \gamma: & \begin{array}{l}\text { Peroxisome proliferator-activated } \\ \text { receptor } \gamma\end{array} \\ \text { PDE: } & \begin{array}{l}\text { Phosphodiesterase } \\ \text { SREBP-1c: }\end{array} \\ & \begin{array}{l}\text { Sterol regulatory element binding } \\ \text { protein-1c }\end{array} \\ \text { UCP3: } & \text { Mitochondrial uncoupling protein-3. }\end{array}$

\section{Conflict of Interests}

The authors declare no conflict of interests. No funding was received for this work.

\section{References}

[1] S. R. Bird and J. A. Hawley, "Exercise and type 2 diabetes: new prescription for an old problem," Maturitas, vol. 72, no. 4, pp. 311-316, 2012.

[2] T. Church, "Exercise in obesity, metabolic syndrome, and diabetes," Progress in Cardiovascular Diseases, vol. 53, no. 6, pp. 412-418, 2011.

[3] C. A. Conn, R. A. Vaughan, and W. S. Sherman, "Nutritional genetics and energy metabolism in human obesity," Current Nutrition Reports, vol. 2, no. 3, pp. 142-150, 2013.

[4] R. Hursel, W. Viechtbauer, and M. S. Westerterp-Plantenga, "The effects of green tea on weight loss and weight maintenance: a meta-analysis," International Journal of Obesity, vol. 33, no. 9, pp. 956-961, 2009.

[5] R. Hursel, W. Viechtbauer, A. G. Dulloo et al., "The effects of catechin rich teas and caffeine on energy expenditure and fat oxidation: a meta-analysis," Obesity Reviews, vol. 12, no. 7, pp. e573e581, 2011.

[6] S. Hasani-Ranjbar, N. Nayebi, B. Larijani, and M. Abdollahi, "A systematic review of the efficacy and safety of herbal medicines used in the treatment of obesity," World Journal of Gastroenterology, vol. 15, no. 25, pp. 3073-3085, 2009.

[7] R. B. Saper, D. M. Eisenberg, and R. S. Phillips, "Common dietary supplements for weight loss," American Family Physician, vol. 70, no. 9, pp. 1731-1738, 2004.

[8] R. L. Bailey, J. J. Gahche, P. E. Miller, P. R. Thomas, and J. T. Dwyer, "Why US adults use dietary supplements," Jama Internal Medicine, vol. 173, no. 5, pp. 355-361, 2013.

[9] P. A. Daly, D. R. Krieger, A. G. Dulloo, and J. B. Young, "Ephedrine, caffeine and aspirin: safety and efficacy for treatment of human obesity," International Journal of Obesity, vol. 17, no. 1, pp. S73-S78, 1993.

[10] A. G. Dulloo, C. A. Geissler, A. Collins, and D. S. Miller, "Normal caffeine consumption: influence on thermogenesis and daily energy expenditure in lean and postobese human volunteers," American Journal of Clinical Nutrition, vol. 49, no. 1, pp. 44-50, 1989.
[11] A. G. Dulloo, "Ephedrine, xanthines and prostaglandin-inhibitors: actions and interactions in the stimulation of thermogenesis," International Journal of Obesity, vol. 17, no. 1, pp. S35-S40, 1993.

[12] A. G. Dulloo, C. Duret, D. Rohrer et al., "Efficacy of a green tea extract rich in catechin polyphenols and caffeine in increasing 24-h energy expenditure and fat oxidation in humans," American Journal of Clinical Nutrition, vol. 70, no. 6, pp. 1040-1045, 1999.

[13] A. G. Dulloo, J. Seydoux, L. Girardier, P. Chantre, and J. Vandermander, "Green tea and thermogenesis: interactions between catechin-polyphenols, caffeine and sympathetic activity," International Journal of Obesity, vol. 24, no. 2, pp. 252-258, 2000.

[14] A. G. Dulloo, "The search for compounds that stimulate thermogenesis in obesity management: from pharmaceuticals to functional food ingredients," Obesity Reviews, vol. 12, no. 10, pp. 866-883, 2011.

[15] K. J. Acheson, B. Zahorska-Markiewicz, and P. P. Pittet Ph., "Caffeine and coffee: their influence on metabolic rate and substrate utilization in normal weight and obese individuals," American Journal of Clinical Nutrition, vol. 33, no. 5, pp. 989$997,1980$.

[16] K. J. Acheson, G. Gremaud, I. Meirim et al., "Metabolic effects of caffeine in humans: lipid oxidation or futile cycling?" American Journal of Clinical Nutrition, vol. 79, no. 1, pp. 40-46, 2004.

[17] S. J. Stohs, H. G. Preuss, S. C. Keith, P. L. Keith, H. Miller, and G. R. Kaats, "Effects of p-synephrine alone and in combination with selected bioflavo-noids on resting metabolism, blood pressure, heart rate and self-reported mood changes," International Journal of Medical Sciences, vol. 8, no. 4, pp. 295-301, 2011.

[18] S. J. Stohs, H. G. Preuss, and M. Shara, "The safety of Citrus aurantium (bitter orange) and its primary protoalkaloid $p$-synephrine," Phytotherapy Research, vol. 25, no. 10, pp. 1421-1428, 2011.

[19] S. J. Stohs, H. G. Preuss, and M. Shara, "A review of the human clinical studies involving Citrus aurantium (bitter orange) extract and its primary protoalkaloid p-synephrine," International Journal of Medical Sciences, vol. 9, no. 7, pp. 527-538, 2012.

[20] S. Haaz, K. R. Fontaine, G. Cutter, N. Limdi, S. PerumeanChaney, and D. B. Allison, "Citrus aurantium and synephrine alkaloids in the treatment of overweight and obesity: an update," Obesity Reviews, vol. 7, no. 1, pp. 79-88, 2006.

[21] A. Basu and E. A. Lucas, "Mechanisms and effects of green tea on cardiovascular health," Nutrition Reviews, vol. 65, no. 8, pp. 361-375, 2007.

[22] A. Belza, S. Toubro, and A. Astrup, "The effect of caffeine, green tea and tyrosine on thermogenesis and energy intake," European Journal of Clinical Nutrition, vol. 63, no. 1, pp. 57-64, 2009.

[23] C.-H. Hsu, T.-H. Tsai, Y.-H. Kao, K.-C. Hwang, T.-Y. Tseng, and P. Chou, "Effect of green tea extract on obese women: a randomized, double-blind, placebo-controlled clinical trial," Clinical Nutrition, vol. 27, no. 3, pp. 363-370, 2008.

[24] Y.-H. Kao, R. A. Hiipakka, and S. Liao, "Modulation of endocrine systems and food intake by green tea epigallocatechin gallate," Endocrinology, vol. 141, no. 3, pp. 980-987, 2000.

[25] M. A. Potenza, F. L. Marasciulo, M. Tarquinio et al., "Epigallocatechin gallate (EGCG), a green tea polyphenol, reduces blood pressure, improves insulin sensitivity, and protects against myocardial Ischemia/Reperfusion (I/R) injury in Spontaneously Hypertensive Rats (SHR)," Diabetes, vol. 55, pp. A126-A126, 2006. 
[26] D. N. Sarma, M. L. Barrett, M. L. Chavez et al., "Safety of green tea extracts: a systematic review by the US Pharmacopeia," Drug Safety, vol. 31, no. 6, pp. 469-484, 2008.

[27] N. P. Seeram, S. M. Henning, Y. Niu, R. Lee, H. S. Scheuller, and D. Heber, "Catechin and caffeine content of green tea dietary supplements and correlation with antioxidant capacity," Journal of Agricultural and Food Chemistry, vol. 54, no. 5, pp. 1599-1603, 2006.

[28] V. R. Sinija and H. N. Mishra, "Green tea: health benefits," Journal of Nutritional \& Environmental Medicine, vol. 17, no. 4, pp. 232-242, 2008.

[29] S. Wolfram, Y. Wang, and F. Thielecke, "Anti-obesity effects of green tea: from bedside to bench," Molecular Nutrition and Food Research, vol. 50, no. 2, pp. 176-187, 2006.

[30] M. C. Lonac, J. C. Richards, M. M. Schweder, T. K. Johnson, and C. Bell, "Influence of short-term consumption of the caffeinefree, epigallocatechin-3-gallate supplement, teavigo, on resting metabolism and the thermic effect of feeding," Obesity, vol. 19, no. 2, pp. 298-304, 2011.

[31] A. B. Hodgson, R. K. Randell, and A. E. Jeukendrup, "The effect of green tea extract on fat oxidation at rest and during exercise: evidence of efficacy and proposed mechanisms," Advances in Nutrition, vol. 4, pp. 129-140, 2013.

[32] E. D. Ryan, T. W. Beck, T. J. Herda et al., "Acute effects of a thermogenic nutritional supplement on energy expenditure and cardiovascular function at rest, during low-intensity exercise, and recovery from exercise," Journal of Strength and Conditioning Research, vol. 23, no. 3, pp. 807-817, 2009.

[33] K. Diepvens, K. R. Westerterp, and M. S. Westerterp-Plantenga, "Obesity and thermogenesis related to the consumption of caffeine, ephedrine, capsaicin, and green tea," American Journal of Physiology: Regulatory Integrative and Comparative Physiology, vol. 292, no. 1, pp. R77-R85, 2007.

[34] A. Belza and A. B. Jessen, "Bioactive food stimulants of sympathetic activity: effect on 24-h energy expenditure and fat oxidation," European Journal of Clinical Nutrition, vol. 59, no. 6, pp. 733-741, 2005.

[35] A. Belza, E. Frandsen, and J. Kondrup, "Body fat loss achieved by stimulation of thermogenesis by a combination of bioactive food ingredients: a placebo-controlled, double-blind 8-week intervention in obese subjects," International Journal of Obesity, vol. 31, no. 1, pp. 121-130, 2007.

[36] F. Greenway, L. de Jonge-Levitan, C. Martin, A. Roberts, I. Grundy, and C. Parker, "Dietary herbal supplements with phenylephrine for weight loss," Journal of Medicinal Food, vol. 9, no. 4, pp. 572-578, 2006.

[37] R. J. Bloomer, R. E. Canale, M. M. Blankenship, K. G. Hammond, K. H. Fisher-Wellman, and B. K. Schilling, "Effect of the dietary supplement Meltdown on catecholamine secretion, markers of lipolysis, and metabolic rate in men and women: a randomized, placebo controlled, cross-over study," Lipids in Health and Disease, vol. 8, article 32, 2009.

[38] J. R. Hoffman, J. Kang, N. A. Ratamess, S. L. Rashti, C. P. Tranchina, and A. D. Faigenbaum, "Thermogenic effect of an acute ingestion of a weight loss supplement," Journal of the International Society of Sports Nutrition, vol. 6, article 1, 2009.

[39] J. Jitomir, E. Nassar, J. Culbertson et al., "The acute effects of the thermogenic supplement Meltdown on energy expenditure, fat oxidation, and hemodynamic responses in young, healthy males," Journal of the International Society of Sports Nutrition, vol. 5, article 23, 2008.
[40] J. Outlaw, C. Wilborn, A. Smith et al., "Effects of ingestion of a commercially available thermogenic dietary supplement on resting energy expenditure, mood state and cardiovascular measures," Journal of the International Society of Sports Nutrition, vol. 10, article 25, 2013.

[41] S. Snitker, Y. Fujishima, H. Shen et al., "Effects of novel capsinoid treatment on fatness and energy metabolism in humans: possible pharmacogenetic implications," American Journal of Clinical Nutrition, vol. 89, no. 1, pp. 45-50, 2009.

[42] C. Wilborn, L. Taylor, C. Poole et al., "Effects of ingesting a commercial thermogenic product on hemodynamic function and energy expenditure at rest in males and females," Applied Physiology, Nutrition and Metabolism, vol. 34, no. 6, pp. 1073-1078, 2009.

[43] V. J. Dalbo, M. D. Roberts, J. R. Stout, and C. M. Kerksick, "Acute effects of ingesting a commercial thermogenic drink on changes in energy expenditure and markers of lipolysis," Journal of the International Society of Sports Nutrition, vol. 5, article 6, 2008.

[44] T. Yoneshiro, S. Aita, Y. Kawai, T. Iwanaga, and M. Saito, "Nonpungent capsaicin analogs (capsinoids) increase energy expenditure through the activation of brown adipose tissue in humans," American Journal of Clinical Nutrition, vol. 95, no. 4, pp. 845-850, 2012.

[45] R. A. Vaughan, R. Garcia-Smith, M. Bisoffi, C. A. Conn, and K. A. Trujillo, "Conjugated linoleic acid or omega 3 fatty acids increase mitochondrial biosynthesis and metabolism in skeletal muscle cells," Lipids in Health and Disease, vol. 11, article 142, 2012.

[46] R. A. Vaughan, R. Garcia-Smith, M. Bisoffi, K. A. Trujillo, and C. A. Conn, "Treatment of human muscle cells with popular dietary supplements increase mitochondrial function and metabolic rate," vol. 9, no. 1, article 101, 2012. 


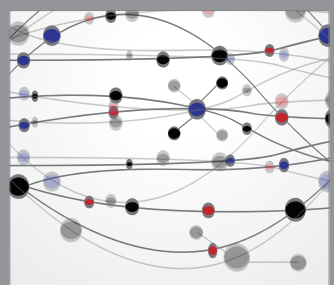

The Scientific World Journal
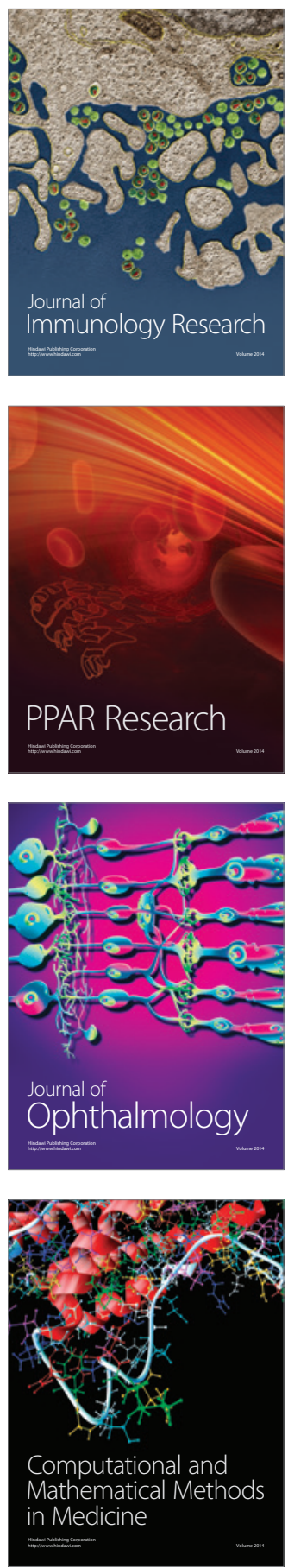

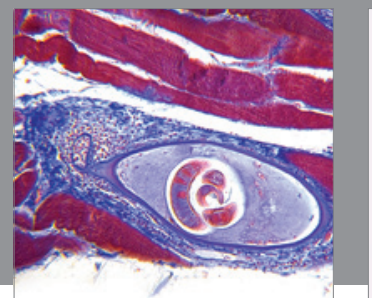

Gastroenterology

Research and Practice
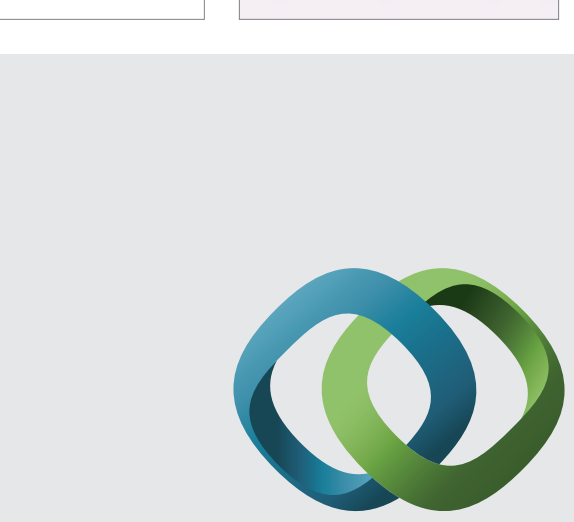

\section{Hindawi}

Submit your manuscripts at

http://www.hindawi.com
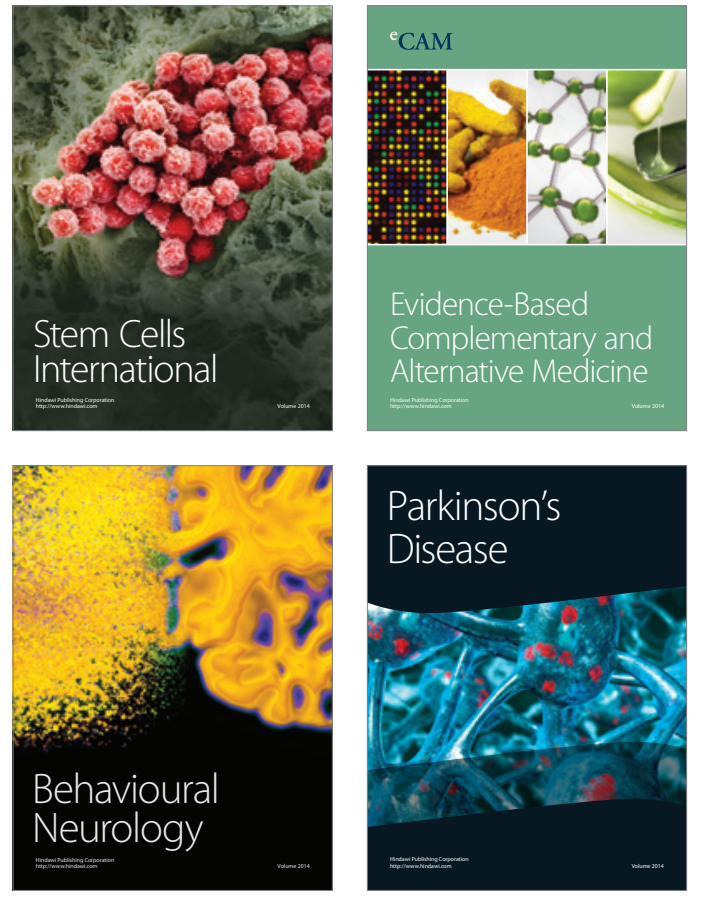
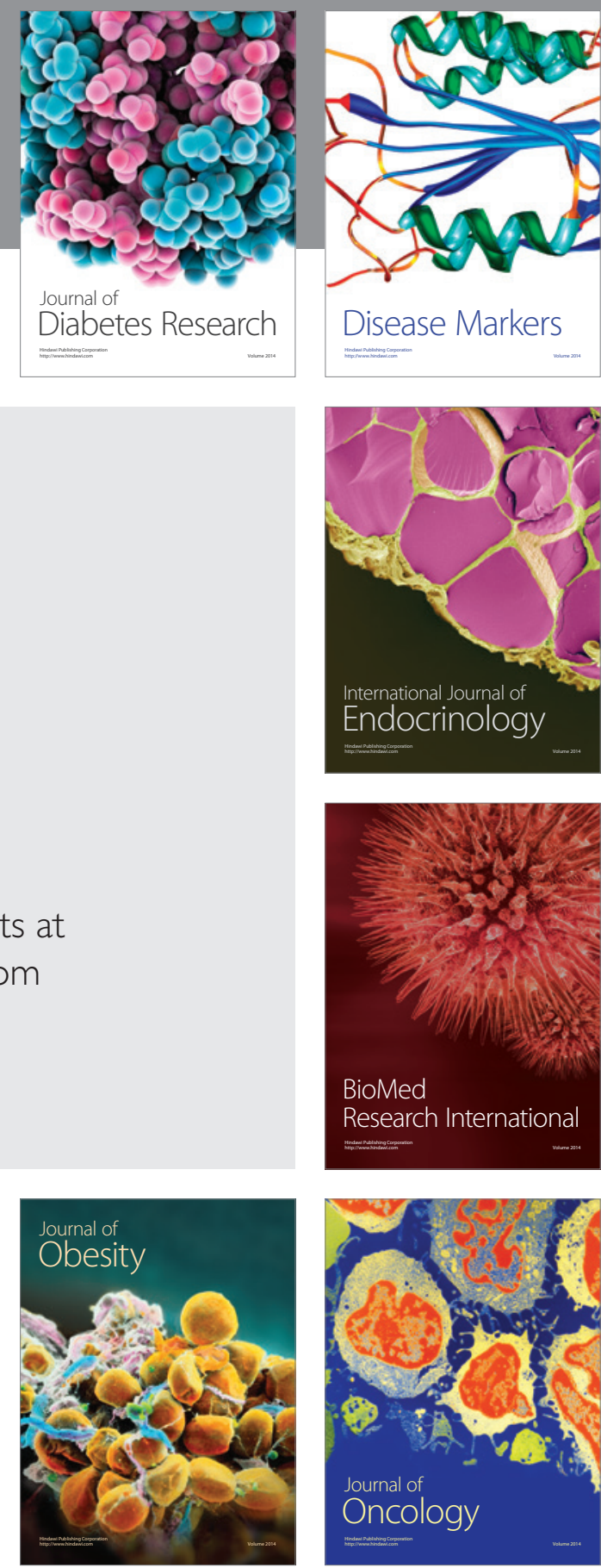

Disease Markers
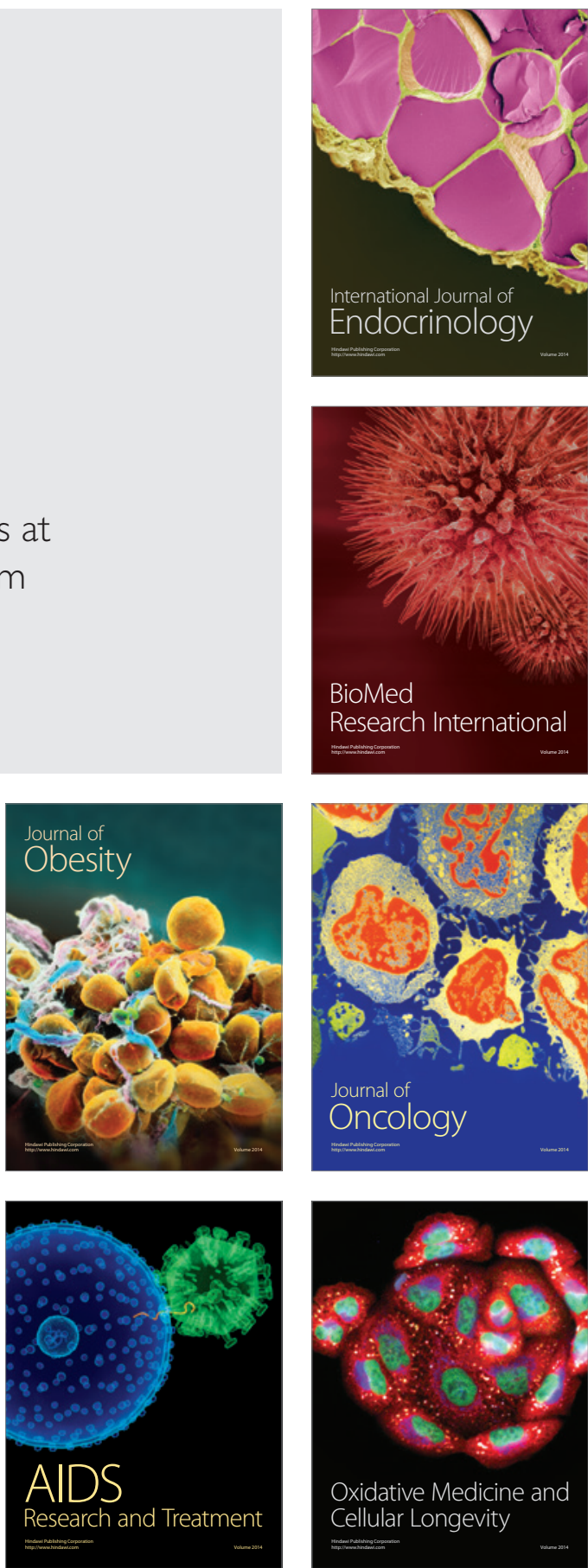